Review

\title{
How genomics has informed our understanding of the pathogenesis of osteoporosis
}

\author{
Mark L Johnson, Nuria Lara and Mohamed A Kamel
}

Address: Department of Oral Biology, University of Missouri - Kansas City School of Dentistry, 650 East 25th Street, Kansas City, MO 64108, USA.

Correspondence: Mark L Johnson. E-mail: johnsonmark@umkc.edu

\begin{abstract}
Osteoporosis is a skeletal disorder characterized by compromised bone strength that predisposes a person to an increased risk of fracture. Osteoporosis is a complex trait that involves multiple genes, environmental factors, and gene-gene and gene-environment interactions. Twin and family studies have indicated that between $25 \%$ and $85 \%$ of the variation in bone mass and other skeletal phenotypes is heritable, but our knowledge of the underlying genes is limited. Bone mineral density is the most common assessment for diagnosing osteoporosis and is the most often used quantitative value in the design of genetic studies. In recent years, our understanding of the pathophysiology of osteoporosis has been greatly facilitated by advances brought about by the Human Genome Project. Genetic approaches ranging from family studies of monogenic traits to association studies with candidate genes, to whole-genome scans in both humans and animals have identified a small number of genes that contribute to the heritability of bone mass. Studies with transgenic and knockout mouse models have revealed major new insights into the biology of many of these identified genes, but much more needs to be learned. Ultimately, we hope that by revealing the underlying genetics and biology driving the pathophysiology of osteoporosis, new and effective treatment can be developed to combat and possibly cure this devastating disease. Here we review the rapidly evolving field of the genomics of osteoporosis with a focus on important gene discoveries, new biological/physiological paradigms that are emerging, and many of the unanswered questions and hurdles yet to be overcome in the field.
\end{abstract}

\section{Introduction}

The past decade has been witness to one of the greatest scientific efforts and achievements in recorded history, the Human Genome Project (HGP). The impact of this effort in terms of our understanding of the genetic basis of disease will be manifest in multiple ways for many decades, even centuries, to come. In the field of osteoporosis, as in all diseases that have a genetic component, the sequencing and cataloguing of the repertoire of genes in the human genome and other species, the development of high- density single nucleotide polymorphism (SNP) maps, highthroughput sequencing along with other genomic technologies, advances in statistical approaches for the analysis of the derived genetic information, and the ability to generate transgenic and knockout mouse models to assess the contribution of individual genes to bone mass regulation have propelled research in the field at an incredible pace.

As in all genetic studies, the choice of phenotype ultimately determines the end-product of the genetic analysis, that is, the genes that may eventually be identified. In the simplest terms, osteoporosis has been defined by The National Institutes of Health (NIH) Consensus Development Panel on Osteoporosis Prevention, Diagnosis, and Therapy as a '...skeletal disorder characterized by compromised bone strength predisposing a person to an increased risk of fracture' [1]. However, this definition offers little phenotypic guidance for the design of studies to dissect out the underlying genetics or for identifying the causal genes of the disease. The World Health Organization Study Group suggested an operational definition for osteoporosis of a bone mineral density (BMD) of 2.5 standard deviations below the mean for young healthy adult women [2]. This definition is widely used today, but does not take into account bone microarchitecture and/or bone quality, which are much more difficult to define. BMD does provide a quantitative variable that can serve as a surrogate for 'osteoporosis' and thus is useful for genetic studies. As such, BMD has been one of the primary phenotypes used in genetic studies of osteoporosis, although as will be briefly referenced in this review there are several other surrogate phenotypes that have also been used in this regard.

\section{Lessons from 'the early days'}

In order to fully appreciate how genomics has informed our understanding of the pathogenesis of osteoporosis, a

BAC, bacterial artificial chromosome; BMD, bone mineral density; HBM, high bone mass; HGP, Human Genome Project; IL, interleukin; LRP5, low density lipoprotein-related protein 5; NIH, National Institutes of Health; OPG, osteoprotegerin; OPPG, osteoporosis pseudoglia syndrome; QTL, quantitative trait locus; PTH, parathyroid hormone; RANKL, receptor activator of nuclear factor KB ligand; SNP, single nucleotide polymorphism; TGF, transforming growth factor; VDR, vitamin D receptor. 
short historical review to provide perspective seems warranted. Osteoporosis is a complex trait involving multiple genes, strong environmental influences and, between individuals, a variable mix of gene-gene and gene-environment interactions. Evidence from twin and family studies has suggested that the heritability of BMD and other skeletal phenotypes ranges between $25 \%$ and $85 \%[3,4]$. Given the high heritability of some of these bone traits (as surrogates for osteoporosis), there is reason to be optimistic that the underlying disease-causing genes can be identified.

\section{Candidate genes}

The entrée of the bone field into the identification of genes involved in 'osteoporosis' was launched by Eisman and colleagues in 1992, with their seminal work on vitamin D receptor gene (VDR) polymorphisms [5]. This report was quickly followed by a number of studies (now totaling over 400) on $V D R$ polymorphisms in relation to BMD and several other phenotypes. Not surprisingly, some studies showed positive associations [6-8], negative correlations [9-11] and some positive or negative correlations depending on phenotype [12,13]. While on the surface this might seem paradoxical, what these studies demonstrated with this single candidate gene approach is that differences in skeletal site, ethnicity, sex, age, menopausal status and diet all have effects that may account for why a candidate gene could have a positive association in one study and not in another. Even more important, these studies illustrated the need for careful study design, including the choice of phenotype, consideration of sample size, choice of study population and statistical methods of analysis, in order to be able to tease out the underlying genetic basis of osteoporosis.

Following the first report on VDR gene polymorphisms, several other favorite candidate gene studies (estrogen receptor (ESR1, ESR2), collagen type 1 (COL1A1), parathyroid hormone $(P T H)$, calcitonin $(C A L C A)$, transforming growth factor- $\beta$ (TGFB1), and so on) began to appear, again with variable positive and negative correlations [14]. These studies all began in the pre-HGP later half of the decade of the 1990 s and mainly used polymerase chain reaction (PCR) to amplify gene fragments with known restriction enzymebased polymorphisms in candidate genes that were chosen based on their known role in bone biology. As the field evolved from a candidate gene focus towards more genomewide approaches, the hope remained that the number of genes would be limited to a few with a 'large effect size', as the technology and statistical methods had not yet reached a capability of dealing with a large number of genes each accounting for less than $5 \%$ of the phenotypic variation. As we have moved into the post-HGP era, both technology and statistical methods of analysis have reached a level of sophistication that allows us to begin to identify these smalleffect-size genes.

\section{Monogenic traits}

In terms of understanding the pathophysiology of osteoporosis, there were major advances during this pre-HGP period that came out of studies of human families with monogenic traits. Advances in our understanding of osteoclast biology were a direct consequence of the identification of genes causing osteopetrosis [15,16], and osteoblast biology was greatly advanced from studies of both human kindreds and mouse model systems [17-19]. Another major advance in our understanding of bone mass regulation resulted from studies of decreased and increased bone mass conditions as in the case of osteoporosis pseudoglioma syndrome (OPPG) [20] and high bone mass (HBM) [21], respectively. Both were initially mapped to human chromosome 11q12-13 [22,23] using standard linkage mapping approaches. In the case of the HBM family, the genome linkage study after the initial definition of the linkage interval was accomplished in one month because of newly available (at that time) dinucleotide repeat-based human linkage mapping panels that used fluorescencebased detection methods on a DNA sequencing platform [23]. The causal mutations for these two conditions were subsequently shown to lie in the low-density lipoprotein receptor-related protein $5\left(L R P_{5}\right)$ gene [24,25]. Subsequently, several other groups have found mutations in $L R P 5$ that give rise to conditions of low and high bone mass [26-28]. LRP5 is a co-receptor along with the frizzled family of proteins for Wnt proteins, and this discovery introduced the importance of Wnt/ $\beta$-catenin signaling [29] in the regulation of bone mass and, since those initial published reports, it has become one of the most heavily studied areas in bone biology. The discovery of $L R P 5$ also illustrates a major limitation of candidate gene studies; they are based on some knowledge for the selection of genes tested, and the linkage interval containing $L_{R} P_{5}$ had no previous identified genes with a known role in bone biology. Similarly, whole-genome scans have produced a number of potential regions or quantitative trait loci (QTLs); many do not harbor any gene with a known role in bone biology. While this makes actual gene identification potentially more difficult, it also increases the likelihood of revealing unsuspected and dramatic new insights [30-34].

$L R P 5$ polymorphisms have subsequently been investigated for a role in bone mass variation, and the majority of studies report positive associations, but on average only approximately 2 to $3 \%$ of the variance can be explained, depending upon the SNPs and phenotypes examined [35-38]. Thus, while specific mutations in $L^{2} P_{5}$ can have a dramatic effect on bone mass, more common variants of the gene appear to only contribute modestly to changes in BMD and consequently the pathophysiology of osteoporosis. $\mathrm{LRP}_{5}$ and the $\mathrm{Wnt} / \beta$-catenin signaling pathway have been suggested as major targets for the development of new therapies to treat osteoporosis, although this has been the subject of some debate in the literature [39-41]. 
Another important family-based gene discovery that also relates to the Wnt/ $\beta$-catenin signaling pathway was the identification of the SOST gene and its role in the pathogenesis of sclerosteosis [42-44] and van Buchem's disease $[45,46]$. The protein product of the Sost gene, sclerostin, inhibits Wnt/ $\beta$-catenin signaling by binding to LRP 5 and preventing Wnt from binding [47,48]. Sclerostin is thought to be exclusively produced by osteocytes $[49,50]$ and functions on osteoblasts to regulate the pathway. Currently, an antibody to sclerostin is under development as a bone anabolic therapeutic for diseases of low bone mass such as osteoporosis [51].

\section{Animal studies}

Additional advances have came from mouse mapping studies that employed a combination of genetic and genomic approaches to identify the Alox15 gene as an important negative regulator of bone mass in mice [52]. Subsequent studies in humans suggested that variants in $A L O X 12$ but not $A_{L O X_{15}}$ accounted for approximately $3 \%$ of the variation in human bone mass [53,54]. The 12/15-lipoxygenase pathway might therefore be another therapeutic target for osteoporosis [52]. Other genes that have appeared recently from various mouse mapping studies include the Duffy antigen receptor for chemokines (Darc) [55], endothelin-converting enzyme 1 (Ece1) [56] and secreted frizzled related-protein 4 (sFRP4) [57]. Whether these genes will contribute to bone mass variation in humans has not yet been fully investigated.

Several QTLs in the mouse have been identified [58-60] and it appears that the locations of these loci vary between inbred lines of mice. This can partially be explained by the known differences in geometry and BMD that is known to exist between strains [58]. One advantage of the mouse models besides the ability to generate specific breeding crosses is the ability to perform functional testing that cannot be carried out in humans, and thereby identify a different set of genes underlying these phenotypes [56,61,62]. Completion of the mouse genome DNA sequence and development of dense marker maps will greatly facilitate the identification of the genes underlying these mouse QTLs, in a similar way to the advances made in human studies.

Mapping studies in other animal model systems such as the baboon [63-65], chicken [66] and cow [67] have also been reported in the literature. Because of its close genetic relatedness to humans, the baboon offers an excellent model system and has been used in an integrative approach using chromosomal syntenic overlaps to define QTLs that are shared between species [63,68].

\section{Recent advances}

In recent years, there has been a literal explosion in the number of published reports based on SNP-based candidate gene studies and whole-genome scans employing different phenotypes and study designs [30,31,69-71]. This can largely be attributed to the development of physical maps, cataloguing of genes and development of high-density SNP maps along with high-throughput technology platforms and statistical advances that came out of the HGP. A comprehensive description of these published reports is not within the scope of this review and so we will highlight just a few of the studies. What is perhaps the most exciting aspect of the more recent studies is that the first genes associated with these various traits are beginning to be identified, and this holds great promise for advancing our understanding of the pathophysiology of osteoporosis.

\section{Genome scans identify numerous QTLs}

A recent review by Ferrari [4] summarizes the location of BMD-related QTLs that have been reported for the human genome and those that have been confirmed by metaanalysis. Interestingly, QTLs have been found on every human autosome, but only a subset has been confirmed by meta-analysis. The first of the genes to be identified from a whole-genome scan was $B M P 2$, which came out of an analysis of extended osteoporotic families in Iceland and a subsequent follow-up association analysis [33]. Other genes that have been associated with BMD and/or fractures include $V D R$, estrogen receptor alpha (ESR1) and beta (ESR2), collagen type $1 \alpha$ (COL1A1), LRP 5 , TGF- $\beta$ (TGFB1), interleukin-6 (IL6), osteoprotegerin or OPG (TNFRSF11b) and receptor activator of nuclear factor $\mathrm{\kappa B}$ ligand or RANKL (TNFSF11). Recently LTBP2 [72] and signal transducer and activator of transcription (STAT1) [73] have also been proposed to be genes involved in osteoporotic phenotypes. STAT1 is an interesting candidate, as the Stat1 ${ }^{--}$mouse has increased bone mass and has been shown to function as an attenuator of Runx2-mediated osteoblast differentiation [74]. Given the large number of candidate intervals identified from the whole-genome scan studies, and the potential large number of genes within those intervals, the next step towards underlying gene identification will be refinement of the mapped intervals. Based on the Icelandic population study [75], refinement of established genomewide significant loci resulted in the identification of prime candidate genes MAP/microtubule affinity-regulating kinase 3 (MARK3) and SOST. Another approach is to combine data from multiple genome-wide studies and perform meta-analysis [4] to focus initial efforts for fine mapping of intervals. Interestingly, new intervals have appeared from this type of analysis [76], likely due to the sample size and power to detect small effect loci that is often the case with any one study. Added into this mix is a consideration of the relative contribution that one particular gene may have in one ethnic group versus another population. Also, in addition to choice of phenotype, which can yield different QTLs and genes, overlapping and different QTLs in males versus females have been identified in several of the published studies $[30,34,69,71,76,77]$. Clearly the gene discovery process is far from over at this point. 


\section{Mouse genomic/genetic approaches}

While the identification of an underlying trait gene within one of the QTLs is an important first step, understanding how this gene relates to pathophysiology of osteoporosis is even more important. In this regard, advances in genomics have played another critical role. Bacterial artificial chromosome (BAC) recombineering $[78,79]$ has become a mainline approach in the bone field, and the pace with which these genetic mouse models can be generated is no longer a rate-limiting step for understanding gene function. The ability to create transgenic and knockout mice to explore the gene function has become a main investigative tool for bone biologists. The development of various Cre recombinase lines of mice in which Cre expression is driven by bone cell-specific promoter elements has propelled the field forward rapidly in the past few years. Crossing these mice with a mouse line containing floxed alleles of the particular gene of interest has provided us with the means to examine the role of any gene in just about any tissue or cell type for a role in bone biology. These conditional knockout mice represent an alternative approach to overcome the lethality of gene deletion that can be encountered in a traditional global knockout approach. In the bone field, mice such as the human osteocalcin-Cre [8o], rat $3.6 \mathrm{~kb}$ Col1-Cre and $2.3 \mathrm{~kb}$ Col1Cre [81] and the mouse $\alpha 1$ (I)-Col-Cre [82] are commonly used for selective deletion of genes in osteoblastic cells; the DMP-1 Cre mouse is used for deletion of genes in osteocytes [83] and the Trap-Cre and Cathepsin-Cre [84] mice can be used for deletion of genes in osteoclasts. A common refinement of these Cre approaches is to include an inducible control element in the promoter construct [85] to overcome lethality problems that can sometimes be encountered even with conditional knockout crosses. However, all of these Cre approaches are not without limitations. As different promoters are used to drive Cre, the cell/tissue specificity and extent of gene deletion in each model system/cross needs to be carefully determined, especially with respect to the developmental pattern and timing of expression as well as the extent to which potential cells downstream in a differentiation pathway are affected, in order to fully interpret the results.

Nonetheless, considerable advances in our understanding of bone biology have resulted from the use of these mouse genetic approaches. For example, we now appreciate that bone plays a key role in several endocrine loops. Recent studies have suggested that bone mass is partially regulated by a fat-brain-bone axis involving leptin and the sympathetic nervous system [86,87]. Also, a key role for the skeleton in the regulation of energy metabolism involving osteoblast-produced osteocalcin has been shown [88]. Finally, bone mass regulation by a gut-brain-bone axis involving serotonin [89] has been proposed. The serotonin story is also interesting from the perspective that Lrp5 expression in the gut rather than the osteoblast has been proposed to be the critical site for Lrp5-mediated bone mass regulation. While this finding will require independent confirmation, it potentially adds another level of complexity to bone mass regulation and raises an important question of what tissue key genes need to be expressed in. Obviously these proposed endocrine loop systems are complicated and there are published data to suggest that there may be different effects on trabecular versus cortical bone [90,91], which adds an additional level of complexity. Regardless of how these evolving stories ultimately turn out, what they clearly illustrate is that bone mass regulation is also dependent on other organ systems besides the classical parathyroid-kidney-gut level of regulation that controls calcium and phosphate homeostasis. These new endocrine loop systems point out the complex nature of the regulation of bone mass and the need to not restrict genomic and functional study efforts solely to genes expressed in bone.

\section{Other approaches and advances}

Gene-expression studies in the bone field have yet to be fully integrated into the genomic effort. There are many reasons for this lack of integration, mainly relating to the difficulty of obtaining appropriate human bone or other tissue samples (besides blood) for conducting expression profiling. One success in this regard was the combination of mapping and gene expression microarray analysis to identify Alox15 as an important regulator of bone mass in mice [52]. A recent report combined gene expression profiling in isolated human peripheral monocytes with a genome-wide association study to identify the STAT1 gene [73], but human expression profiling relating to osteoporosis has lagged far behind other diseases.

Another important recent development is related to our understanding of the multifaceted roles played by the osteocyte. This cell is the most abundant cell type in bone. It is embedded within the mineralized matrix and through the lacunar canalicular system forms a communication network via its dendritic processes with other osteocytes and cells on the bone surfaces and within the vascular beds of bone. The osteocyte has long been thought to be the mechanosensory cell within bone, and as such plays a central role in controlling bone mass in response to changes in load environment. Recent studies have now shown that the osteocyte also plays a key role in regulating phosphate metabolism and mineral homeostasis, and orchestrating the activity of the bone-forming osteoblasts and bone-resorbing osteoclasts through autocrine, paracrine and endocrine mechanisms [92]. Osteocytes also appear to be the only cells producing sclerostin, the product of the SOST gene, which modulates the activity of Lrp5/6 and the Wnt signaling pathway. What all of these recent findings illustrate is that bone and bone cells do not exist in their own sequestered environment. Bone mass regulation over an individual's lifetime is finely tuned by a number of factors produced 
Table 1

\begin{tabular}{|c|c|c|c|}
\hline Gene & Signaling pathway & Study design & References \\
\hline LRP5 & Wnt/ß-catenin & Human family linkage, GWAS, CGS, mouse genetics & {$[25-27,70,77,107-109]$} \\
\hline SOST & Wnt/ß-catenin & Human family linkage, GWAS & {$[43,44,46,75]$} \\
\hline sFRP4 & Wnt/ß-catenin & GWAS, CGS, mouse genomics and genetics & {$[57,110,111]$} \\
\hline ALOX $12 / 15$ & Arachidonic acid metabolism & Mouse genomics and genetics, GWAS, CGS & [52-54] \\
\hline$B M P 2$ & Bone morphogenetic protein signaling & GWAS, CGS, mouse genomics and genetics & {$[33,112,113]$} \\
\hline VDR & Transcriptional regulation & CGS, GWAS & {$[5,32,107]$} \\
\hline ESR1/ESR2 & Transcriptional regulation & CGS, GWAS & {$[4,72,107]$} \\
\hline STAT1 & Transcriptional regulation & GEP, CGS, mouse genetics & {$[73,74]$} \\
\hline Col1A1 & Extracellular matrix & CGS, GWAS & {$[3,32]$} \\
\hline
\end{tabular}

CGS, candidate gene study; GEP, gene expression profiling; GWAS, genome-wide association study. For additional references see article and reviews cited therein.

from both outside and within bone. As such, there is still a great amount of bone biology that we do not yet know, and a combination of genomic, proteomic and other approaches will be needed to fully understand the pathophysiology of bone diseases like osteoporosis.

\section{Conclusions}

Advances in genomics have propelled discovery in the bone field forward at an ever-accelerating pace, but there is still much to be learned. How many genes will ultimately be involved in explaining variation in BMD or other bone phenotypes is clearly an open question at this time. Given the new insights recently achieved regarding the complexities of bone mass regulation, it seems likely that many of the genes that will be discovered in the near future will be expressed in tissues other than bone, and understanding this will be an important aspect of future genomic efforts.

Given the pace of research, it seems almost certain that we will eventually catalogue the entire repertoire of genes that contribute to the pathophysiology of osteoporosis. It is not unreasonable to believe that in the near future, technology platforms will evolve to the point where sequencing one's entire genome will become feasible. New approaches to high-throughput sequencing are currently being developed, with real potential to make this a reality [93-95]. This implies that individual whole-genome analysis is not that far away. However, one major lesson from previous research is that within individuals, or groups of individuals, only a subset of genes may play a predominant role. Furthermore, in the case of osteoporosis, which is mainly a disease of older age and involves not only genetic, but also environmental, gene-gene and gene-environment interactions, determining lifetime risk will be much more complicated. One of the great challenges going forward will be not only identifying the genes, but also understanding how these genes are influenced by other factors.
Ultimately we hope to fully understand the pathophysiology of osteoporosis so that effective treatment can be achieved. As shown in Table 1, several genes have now been identified that contribute to the variation in bone density or other phenotypes. Three of the strongest candidate genes that have currently been identified are components of the Wnt/ $\beta$-catenin signaling pathway. An antibody to sclerostin is already being developed; it is an anabolic agent and initial studies in rats have demonstrated a significant increase in BMD and show great promise [51]. Also, a series of sulfonamide derivatives have been shown to modulate Wnt signaling through inhibition of sFRP-1 [96], suggesting another class of compounds that might be developed into a therapeutic agent to increase bone mass. Other targets such as GSK-3 $\beta$ [97,98] and Dickkopf-1 [99,100] have been described in the literature. A major concern with targeting the Wnt pathway is its known role in tumor formation and whether manipulating the pathway in bone will increase the risk of tumor formation in other tissues [39,41,101-106]. Manipulating sclerostin appears to circumvent this concern because it is produced by osteocytes and therefore potentially restricts the target to bone, although the extent to which sclerostin circulates could be a potential unknown issue that will need to be resolved. While it appears that a new generation of anabolic agents is now on the horizon, clearly our understanding of the underlying genetics of osteoporosis has yet to reveal all there is to be discovered. Looking further ahead as new agents for treating osteoporosis are developed, studies will be needed to understand how any given individual's response to different therapeutic approaches may vary as a function of their specific genetic background. Clearly, advances in genomics will also play a major role in addressing and solving these and many other future questions.

\section{Competing interests}

The authors declare that they have no competing interests. 


\section{Authors' contributions}

The authors shared equally in the writing of this review and agree to its content.

\section{Acknowledgements}

MLJ is supported by grants from NIH/NIAMS grants RO1 AR053949 and PO1 AR046798 and NIH/NIA RO1 AG030637.

\section{References}

1. NIH Consensus Development Panel on Osteoporosis Prevention and Therapy: Osteoporosis prevention, diagnosis and therapy. JAMA 2001, 285:785-795.

2. Kanis JA Melton 3rd LJ, Christiansen C, Johnston CC, Khaltaev N: The diagnosis of osteoporosis. J Bone Miner Res 1994, 9:1137-1141.

3. Ralston SH: Genetic control of susceptibility to osteoporosis. J Clin Endocrinol Metab 2002, 87:2460-2466.

4. Ferrari S: Human genetics of osteoporosis. Best Pract Res Clin Endocrinol Metab 2008, 22:723-735.

5. Morrison NA, Yeoman R, Kelly PJ, Eisman JA: Contribution of trans-acting factor alleles to normal physiological variability: vitamin $\mathrm{D}$ receptor gene polymorhpisms and circulating osteocalcin. Proc Natl Acad Sci USA 1992, 89:6665-6669.

6. Houston LA, Grant SF, Reid DM, Ralston SH: Vitamin D receptor polymorphism, bone mineral density, and osteoporotic vertebral fracture: studies in a UK population. Bone 1996, 18:249-252.

7. Dawson-Hughes B, Harris SS, Finneran S: Calcium absorption on high and low calcium intakes in relation to vitamin D receptor genotype. J Clin Endocrinol Metab 1995, 80:36573661.

8. Riggs BL, Nguyen TV, Melton LJ, 3rd, Morrison NA, O'Fallon WM, Kelly PJ, Egan KS, Sambrook PN, Muhs JM, Eisman JA: The contribution of vitamin $D$ receptor gene alleles to the determination of bone mineral density in normal and osteoporotic women. J Bone Miner Res 1995, 10:991-996.

9. Garnero P, Borel O, Sornay-Rendu E, Arlot ME, Delmas PD: Vitamin $D$ receptor gene polymorphisms are not related to bone turnover, rate of bone loss, and bone mass in postmenopausal women: the OFELY study. J Bone Miner Res 1996, 11:827-834.

10. Boschitsch E, Suk EK, Mayr WR, Lang T, Schwartz WM, Panzer S: Genotypes of the vitamin-D-receptor gene and bone mineral density in Caucasoid postmenopausal females. Maturitas 1996, 24:91-96.

11. Arden NK, Keen RW, Lanchbury JS, Spector TD: Polymorphisms of the vitamin $D$ receptor gene do not predict quantitative ultrasound of the calcaneus or hip axis length. Osteoporos Int 1996, 6:334-337.

12. Salamone LM, Ferrell R, Black DM, Palermo L, Epstein RS, Petro N, Steadman N, Kuller LH, Cauley JA: The association between vitamin $D$ receptor gene polymorphisms and bone mineral density at the spine, hip and whole-body in premenopausal women. Osteoporos Int 1996, 6:63-68.

13. Barger-Lux MJ, Heaney RP, Hayes J, DeLuca HF, Johnson ML, Gong G: Vitamin D receptor gene polymorphism, bone mass, body size, and vitamin $D$ receptor density. Calcif Tissue Int 1995, 57:161-162.

14. Liu YZ, Liu YJ, Recker RR, Deng HW: Molecular studies of identification of genes for osteoporosis: the 2002 update. $J$ Endocrinol 2003, 177:147-196.

15. Frattini A, Orchard PJ, Sobacchi C, Giliani S, Abinun M, Mattsson JP, Keeling DJ, Andersson AK, Wallbrandt P, Zecca $L$, Notarangelo LD, Vezzoni P, Villa A: Defects in TCIRG1 subunit of the vacuolar proton pump are responsible for a subset of human autosomal recessive osteopetrosis. Nat Genet 2000, 25:343-346.

16. Kornak U, Kasper D, BosI MR, Kaiser E, Schweizer M, Schulz A, Friedrich W, Delling G, Jentsch TJ: Loss of the CIC-7 chloride channel leads to osteopetrosis in mice and man. Cell 2001, 26:205-215
17. Komori T, Yagi H, Nomura S, Yamaguchi A, Sasaki K, Deguchi K, Shimizu Y, Bronson RT, Gao YH, Inada M, Sato M, Okamoto R, Kitamura Y, Yoshiki S, Kishimoto T: Targeted disruption of Cbfa1 results in a complete lack of bone formation owing to maturational arrest of osteoblasts. Cell 1997, 89:755-764.

18. Otto F, Thornell AP, Crompton T, Denzel A, Gilmour KC, Rosewell IR, Stamp GW, Beddington RS, Mundlos S, Olsen BR, Selby PB, Owen MJ: Cbfa1, a candidate gene for cleidocranial dysplasia syndrome, is essential for osteoblast differentiation and bone development. Cell 1997, 89:765771

19. Mundlos S, Otto F, Mundlos C, Mulliken JB, Aylsworth AS, Albright S, Lindhout D, Cole WG, Henn W, Knoll JH, Owen MJ, Mertelsmann R, Zabel BU, Olsen BR: Mutations involving the transcription factor CBFA1 cause cleidocranial dysplasia. Cell 1997, 89:773-779.

20. Osteoporosis-Pseudoglioma Syndrome; OPPG [http://www ncbi.nlm.nih.gov/entrez/dispomim.cgi?id=259770] (accessed 25 August 2009).

21. Bone Mineral Density Quantitative Trait Locus 1; BMND1 [http://www.ncbi.nlm.nih.gov/entrez/dispomim.cgi?id=601884] (accessed 25 August 2009).

22. Gong $Y$, Vikkula $M$, Boon L, Liu J, Beighton $P$, Ramesar $R$ Peltonen L, Somer H, Hirose T, Dallapiccola B, De Paepe A, Swoboda W, Zabel B, Superti-Furga A, Steinmann B, Brunner HG, Jans A, Boles RG, Adkins W, van den Boogaard MJ, Olsen BR, Warman ML: Osteoporosis-pseudoglioma syndrome, a disorder affecting skeletal strength and vision, is assigned to chromosome region 11q12-13. Am J Hum Genet 1996, 59: 146-151.

23. Johnson ML, Gong G, Kimberling WJ, Recker SM, Kimmel DK, Recker RR: Linkage of a gene causing high bone mass to human chromosome 11 (11q12-13). Am J Hum Genet 1997, 60:1326-1332.

24. Gong Y, Slee RB, Fukai N, Rawadi G, Roman-Roman S, Reginato AM, Wang H, Cundy T, Glorieux FH, Lev D, Zacharin M, Oexle K, Marcelino J, Suwairi W, Heeger S, Sabatakos G Apte S, Adkins WN, Allgrove J, Arslan-Kirchner M, Batch JA, Beighton P, Black GC, Boles RG, Boon LM, Borrone C, Brunner HG, Carle GF, Dallapiccola B, De Paepe A: LDL receptorrelated protein 5 (LRP5) affects bone accrual and eye development. Cell 2001, 107:513-523.

25. Little RD, Carulli JP, Del Mastro RG, Dupuis J, Osborne M, Folz C, Manning SP, Swain PM, Zhao SC, Eustace B, Lappe MM, Spitzer L, Zweier S, Braunschweiger K, Benchekroun Y, Hu X, Adair R, Chee L, FitzGerald MG, Tulig C, Caruso A, Tzellas N, Bawa A, Franklin B, McGuire S, Nogues X, Gong G, Allen KM Anisowicz A, Morales AJ: A mutation in the LDL receptorrelated protein 5 gene results in the autosomal dominant high-bone-mass trait. Am J Hum Genet 2002, 70:11-19.

26. Boyden LM, Mao J, Belsky J, Mitzner L, Farhi A, Mitnick MA, Wu D, Insogna K, Lifton RP: High bone density due to a mutation in LDL-receptor-related protein 5. $N$ Engl $\mathrm{J}$ Med 2002, 346:1513-1521.

27. Van Wesenbeeck L, Cleiren E, Gram J, Beals RK, Bénichou O, Scopelliti D, Key L, Renton T, Bartels C, Gong Y, Warman ML, De Vernejoul MC, Bollerslev J, Van Hul W: Six novel missense mutations in the LDL receptor-related protein5 (LRP5) gene in different conditions with an increased bone density. Am J Hum Genet 2003, 72:763-771.

28. Streeten EA, Morton H, McBride DJ: Osteoporosis pseudoglioma syndrome: 3 siblings with a novel LRP5 mutation. $J$ Bone Miner Res 2003, 18(Suppl 2):S35.

29. Johnson ML, Harnish K, Nusse R, Van Hul W: LRP5 and Wnt signaling: a union made for bone. J Bone Miner Res 2004 19:1749-1757

30. Ralston SH, Galwey N, MacKay I, Albagha OM, Cardon L, Compston JE, Cooper C, Duncan E, Keen R, Langdahl B, McLellan A, O'Riordan J, Pols HA, Reid DM, Uitterlinden AG, Wass J, Bennett ST: Loci for regulation of bone mineral density in men and women identified by genome wide linkage scan: the FAMOS study. Hum Mol Genet 2005, 14: 943-951. 
31. Chinappen-Horsley U, Blake GM, Fogelman I, Kato B, Ahmadi KR, Spector TD: Quantitative trait loci for bone lengths on chromosome 5 using dual energy X-ray absorptiometry imaging in the Twins UK cohort. PLoS One 2008, 3:e1752.

32. Zmuda JM, Sheu YT, Moffett SP: The search for human osteoporosis genes. J Musculoskelet Neuronal Interact 2006, 6: 3-15.

33. Styrkarsdottir $U$, Cazier JB, Kong A, Rolfsson $\mathrm{O}$, Larsen $\mathrm{H}$, Bjarnadottir E, Johannsdottir VD, Sigurdardottir MS, Bagger Y, Christiansen C, Reynisdottir I, Grant SF, Jonasson K, Frigge ML, Gulcher JR, Sigurdsson G, Stefansson K: Linkage of osteoporosis to chromosome 20p12 and association to BMP2. PLoS Biol 2003, 1:E69.

34. Xiong DH, Wang JT, Wang W, Guo YF, Xiao P, Shen H, Jiang H, Chen Y, Deng H, Drees B, Recker RR, Deng HW: Genetic determination of osteoporosis: lessons learned from a large genome-wide linkage study. Hum Biol 2007, 79:593608

35. Mizuguchi T, Furuta I, Watanabe $\mathrm{Y}$, Tsukamoto $\mathrm{K}$, Tomita $\mathrm{H}$, Tsujihata M, Ohta T, Kishino T, Matsumoto N, Minakami H, Niikawa N, Yoshiura K: LRP5, low-density-lipoprotein-receptor-related protein 5 , is a determinant for bone mineral density. J Hum Genet 2004, 49:80-86.

36. Bollerslev J, Wilson SG, Dick IM, Islam FM, Ueland T, Palmer L, Devine A, Prince RL: LRP5 gene polymorphisms predict bone mass and incident fractures in elderly Australian women. Bone 2005, 36:599-606.

37. Ferrari SL, Deutsch S, Baudoin C, Cohen-Solal M, Ostertag A, Antonarakis SE, Rizzoli R, de Vernejoul MC: LRP5 gene polymorphisms and idiopathic osteoporosis in men. Bone 2005, 37:770-775

38. Giroux S, Elfassihi L, Cardinal G, Laflamme N, Rousseau F: LRP5 coding polymorphisms influence the variation of peak bone mass in a normal population of FrenchCanadian women. Bone 2007, 40:1299-1307.

39. Baron R, Rawadi G: Targeting the Wnt/ß-catenin pathway to regulate bone formation in the adult skeleton. Endocrinology 2007, 148:2635-2643.

40. Shahnazari M, Yao W, Corr M, Lane NE: Targeting the Wnt signaling pathway to augment bone formation. Curr Osteoporos Rep 2008, 6:142-148.

41. Hoeppner LH, Secreto FJ, Westendorf JJ: Wnt signaling as a therapeutic target for bone diseases. Expert Opin Ther Targets 2009, 13:485-496.

42. Sclerosteosis; SOST [http://www.ncbi.nlm.nih.gov/entrez/dispomim.cgi?id=269500] (accessed 24 August 2009).

43. Brunkow ME, Gardner JC, Van Ness J, Paeper BW, Kovacevich BR, Proll S, Skonier JE, Zhao L, Sabo PJ, Fu Y, Alisch RS, Gillett L, Colbert T, Tacconi P, Galas D, Hamersma $H$, Beighton $P$, Mulligan J: Bone dysplasia sclerosteosis results from loss of the SOST gene product, a novel cystine knot-containing protein. Am J Hum Genet 2001, 68: 577-589.

44. Balemans W, Ebeling M, Patel N, Van Hul E, Olson P, Dioszegi M, Lacza C, Wuyts W, Van Den Ende J, Willems P, Paes-Alves AF, Hill S, Bueno M, Ramos FJ, Tacconi P, Dikkers FG, Stratakis C, Lindpaintner K, Vickery B, Foernzler D, Van Hul W: Increased bone density in sclerosteosis is due to the deficiency of a novel secreted protein (SOST). Hum Mol Genet 2001, 10:537-543

45. Hyperostosis Corticalis Generalisata [http://www.ncbi.nlm. nih.gov/entrez/dispomim.cgi?id=239100] (accessed 24 August 2009).

46. Balemans W, Patel N, Ebeling M, Van Hul E, Wuyts W, Lacza C, Dioszegi M, Dikkers FG, Hildering P, Willems PJ, Verheij JB, Lindpaintner K, Vickery B, Foernzler D, Van Hul W: Identification of a $\mathbf{5 2} \mathbf{~ k b}$ deletion downstream of the SOST gene in pateints with van Buchem disease. $J$ Med Genet 2002, 39:91-97.

47. Semenov M, Tamai $\mathrm{K}, \mathrm{He} \mathrm{X}$ : SOST is a ligand for LRP5/LRP6 and a Wnt signaling inhibitor. J Biol Chem 2005, 280:2677026775.
48. Ellies DL, Viviano B, McCarthy J, Rey JP, Itasaki N, Saunders $S$, Krumlauf $R$ : Bone density ligand, sclerostin, directly interacts with LRP5 but not LRP5G171V to modulate Wnt activity. J Bone Miner Res 2006, 21:1738-1749.

49. van Bezooijen RL, Roelen BA, Visser A, van der Wee-Pals $L$, de Wilt E, Karperien M, Hamersma H, Papapoulos SE, ten Dijke P, Lowik CW: Sclerostin is an osteocyte-expressed negative regulator of bone formation, but not a classical BMP antagonist. J Exp Med 2004, 199:805-814.

50. Winkler DG, Sutherland MK, Geoghegan JC, Yu C, Hayes T, Skonier JE, Shpektor D, Jonas M, Kovacevich BR, StaehlingHampton K, Appleby M, Brunkow ME, Latham JA: Osteocyte control of bone formation via sclerostin, a novel BMP antagonist. EMBO J 2003, 22:6267-6276.

51. Li X, Ominsky MS, Warmington KS, Morony S, Gong J, Cao J, Gao Y, Shalhoub V, Tipton B, Haldankar R, Chen Q, Winters A Boone T, Geng Z, Niu QT, Ke HZ, Kostenuik PJ, Simonet WS, Lacey DL, Paszty C: Sclerostin antibody treatment increases bone formation, bone mass, and bone strength in a rat model of postmenopausal osteoporosis. J Bone Miner Res 2009, 24:578-588.

52. Klein RF, Allard J, Anur Z, Nikolcheva T, Rotstein D, Carlos AS, Shea M, Waters R, Belknap J, Peltz G, Orwoll ES: Regulation of bone mass in mice by the lipoxygenase gene Alox15. Science 2004, 303:229-232.

53. Ichikawa S, Koller DL, Johnson ML, Lai D, Xuei X, Edenberg HJ, Klein RF, Orwoll ES, Hui SL, Foroud TM, Peacock M, Econs MJ: Humna ALOX12, but not ALOX15, is Associated with BMD in white men and women. J Bone Miner Res 2006 , 21:556-564.

54. Mullin BH, Spector TD, Curtis CC, Ong GN, Hart DJ, Hakim AJ, Worthy T, Wison SG: Polymorphisms in ALOX12, but not ALOX15, are significantly associated with BMD in postmenopausal women. Calcif Tissue Int 2007, 81:10-17.

55. Edderkaoui B, Baylink DJ, Beamer WG, Wergedal JE, Porte R, Chaudhuri A, Mohan S: Identification of mouse Duffy antigen receptor for chemokines (Darc) as a BMD QTL gene. Genome Res 2007, 17:577-585.

56. Saless N, Litscher SJ, Lopez Franco GE, Houlihan MJ, Sudhakaran S, Raheem KA, O'Neil TK, Vanderby R, Demant P, Blank RD: Quantitative trait loci for biomechanical performance and femoral geometry in an intercross of recombinant congenic mice: restriction of the $\mathrm{Bmd7}$ candidate interval. FASEB J 2009, 23:2142-2154.

57. Nakanishi R, Shimizu M, Mori M, Akiyama H, Okudaira S, Otsuki B, Hashimoto M, Higuchi K, Hosokawa M, Tsuboyama T, Nakamura T: Secreted frizzled-related protein 4 is a negative regulator of peak BMD in SAMP6 mice. $J$ Bone Miner Res 2006, 21:1713-1721.

58. Wergedal JE, Sheng MH-C, Ackert-Bicknell CL, Beamer WG, Baylink DJ: Genetic variation in femur extrinsic strength in 29 different inbred strains of mice is dependent on variations in femur cross-sectional geometry and bone density. Bone 2005, 36:111-122.

59. Xiong Q, Han C, Beamer WG, Gu W: A close examination of genes within quantitative trait loci of bone mineral density in whole mouse genome. Crit Rev Eukaryot Gene Expr 2008 18:323-343.

60. Xiong Q, Jiao Y, Hasty KA, Canale ST, Stuart JM, Beamer WG, Deng HW, Baylink D, Gu W: Quantitative trait loci, genes, and polymorphisms that regulate bone mineral density in mouse. Genomics 2009, 93:401-414.

61. Yershov $\mathrm{Y}$, Baldini TH, Villagomez S, Young T, Martin M, Bockman RS, Peterson MG, Blank RD: Bone strength and related traits in $\mathrm{HcB} /$ Dem recombinant congenic mice. $J$ Bone Miner Res 2001, 16:992-1003.

62. Kodama Y, Dimai HP, Wergedal J, Sheng M, Malpe R, Kutilek S, Beamer W, Donahue LR, Rosen C, Baylink DJ, Farley J: Cortical tibial bone volume in two strains of mice: effects of sciatic neurectomy and genetic regulation of bone response to mechanical loading. Bone 1999, 25:183-190.

63. Havill LM, Mahaney MC, Cox LA, Morin PA, Joslyn G, Rogers $\mathrm{J}$ : A quantitative trait locus for normal variation in forearm 
bone mineral density in pedigreed baboons maps to the ortholog of human chromosome 11q. J Clin Endocrinol Metab 2005, 90:3638-3645.

64. Havill LM, Rogers J, Cox LA, Mahaney MC: QTL with pleiotropic effects on serum levels of bone-specific alkaline phosphatase and osteocalcin maps to the baboon ortholog of human chromosome 6p23-21.3. J Bone Miner Res 2006, 21:1888-1896

65. Sherwood RJ, Duren DL, Havill LM, Rogers J, Cox LA, Towne $B$, Mahaney MC: A genomewide linkage scan for quantitative trait loci influencing the craniofacial complex in baboons (Papio hamadryas spp.). Genetics 2008, 180:619628.

66. Dunn IC, Fleming RH, McCormack HA, Morrice D, Burt DW, Preisinger R, Whitehead CC: A QTL for osteoporosis detected in an F2 population derived from White Leghorn chicken lines divergently selected for bone index. Anim Genet 2007, 38:45-49.

67. Buitenhuis AJ, Lund MS, Thomasen JR, Thomsen B, Nielsen $\mathrm{VH}$, Bendixen C, Guldbrandtsen B: Detection of quantitative trait loci affecting lameness and leg conformation traits in Danish Holstein cattle. J Dairy Sci 2007, 90:472-481.

68. Havill LM, Cox LA, Rogers J, Mahaney MC: Cross-species replication of a serum osteocalcin quantitative trait locus on human chromosome $16 q$ in pedigreed baboons. Calcif Tissue Int 2005, 77:205-211.

69. Peacock M, Koller DL, Lai D, Hui S, Foroud T, Econs MJ: Bone mineral density variation in men is influenced by sex-specific and non sex-specific quantitative trait loci. Bone 2009, 45:443-448.

70. Richards JB, Rivadeneira F, Inouye M, Pastinen TM, Soranzo N, Wilson SG, Andrew T, Falchi M, Gwilliam R, Ahmadi KR, Valdes AM, Arp P, Whittaker P, Verlaan DJ, Jhamai M, Kumanduri V, Moorhouse M, van Meurs JB, Hofman A, Pols HA, Hart D, Zhai G, Kato BS, Mullin BH, Zhang F, Deloukas P, Uitterlinden AG, Spector TD: Bone mineral density, osteoporosis, and osteoporotic fractures: a genome-wide association study. Lancet 2008, 371:1505-1512.

71. Zhang $F$, Xiao $P$, Yang $F$, Shen $H$, Xiong $D H$, Deng $H Y$, Papasian CJ, Drees BM, Hamilton JJ, Recker RR, Deng HW: A whole genome linkage scan for QTLs underlying peak bone mineral density. Osteoporos Int 2008, 19:303-310.

72. Cheung CL, Shan PC, Chan V, Paterson AD, Luk KDK, Kung AWC: Identification of LTBP2 on chromosome $14 q$ as a novel candidate gene for bone mineral density variation and fracture risk association. J Clin Endocrinol Metab 2008, 93:4448-4455

73. Chen XD, Xiao P, Lei SF, Liu YZ, Guo YF, Deng FY, Tan LJ, Zhu XZ, Chen FR, Recker RR, Deng HW: Gene expression profiling in monocytes and SNP association suggest the importance of STAT1 Gene for osteoporosis in both Chinese and Caucasians. J Bone Miner Res 2009 [Epub ahead of print].

74. Kim S, Koga T, Isobe M, Kern BE, Yokochi T, Chin YE, Karsenty $\mathrm{G}$, Taniguchi T, Takayanagi $\mathrm{H}$ : Stat1 functions as a cytoplasmic attenuator of Runx2 in the transcriptional program of osteoblast differentiation. Genes Dev 2003, 17:1979-1991.

75. Styrkarsdottir U, Halldorsson BV, Gretarsdottir S, Gudbjartsson DF, Walters GB, Ingvarsson T, Jonsdottir T, Saemundsdottir J, Snorradóttir S, Center JR, Nguyen TV, Alexandersen P, Gulcher JR, Eisman JA, Christiansen C, Sigurdsson G, Kong A, Thorsteinsdottir $U$, Stefansson K: New sequence variants associated with bone mineral density. Nat Genet 2009, 41: 15-17.

76. Ioannidis JP, Ng MY, Sham PC, Zintzaras E, Lewis CM, Deng HW, Econs MJ, Karasik D, Devoto M, Kammerer CM, Spector T, Andrew T, Cupples LA, Duncan EL, Foroud T, Kiel DP, Koller D, Langdahl B, Mitchell BD, Peacock M, Recker R, Shen $\mathrm{H}$, Sol-Church K, Spotila LD, Uitterlinden AG, Wilson SG, Kung AW, Ralston SH: Meta-analysis of genome-wide scans provides evidence for sex- and site-specific regulation of bone mass. J Bone Miner Res 2007, 22:173-183.
77. van Meurs JB, Trikalinos TA, Ralston SH, Balcells S, Brandi $\mathrm{ML}$, Brixen $\mathrm{K}$, Kiel DP, Langdahl BL, Lips $\mathrm{P}$, Ljunggren $\mathrm{O}$, Lorenc R, Obermayer-Pietsch B, Ohlsson C, Pettersson U, Reid DM, Rousseau F, Scollen S, Van Hul W, Agueda L, Akesson K, Benevolenskaya LI, Ferrari SL, Hallmans G, Hofman A, Husted LB, Kruk M, Kaptoge S, Karasik D, Karlsson $\mathrm{MK}$, Lorentzon M, et al.: Large-scale analysis of association between LRP5 and LRP6 variants and osteoporosis. JAMA 2008, 299:1277-1290.

78. Parkitna JR, Engblom D, Schutz G: Generation of Cre recombinase-expressing transgenic mice using bacterial artificial chromosomes. Methods Mol Biol 2009, 530:325-342.

79. Ohtsuka M, Kimura M, Tanaka M, Inoko H: Recombinant DNA technologies for construction of precisely designed transgene constructs. Curr Pharm Biotechnol 2009, 10:244-251.

80. Zhang $M$, Xuan $S$, Bouxsein $M L$, von Stechow $D$, Akeno $N$, Faugere MC, Malluche H, Zhao G, Rosen CJ, Efstratiadis A, Clemens TL: Osteoblast-specific knockout of the insulinlike growth factor (IGF) receptor gene reveals an essential role of IGF signaling in bone matrix mineralization. $J$ Biol Chem 2002, 277:44005-44012.

81. Liu F, Woitge HW, Braut A, Kronenberg MS, Lichtler AC, Mina $\mathrm{M}$, Kream BE: Expression and activity of osteoblast-targeted Cre recombinase transgenes in murine skeletal tissues. Int J Dev Biol 2004, 48:645-653.

82. Dacquin $R$, Starbuck M, Schinke T, Karsenty G: Mouse alpha1(I)-collagen promoter is the best known promoter to drive efficient Cre recombinase expression in osteoblast. Dev Dyn 2002, 224:245-251.

83. Lu Y, Xie Y, Zhang S, Dusevich V, Bonewald LF, Feng JQ: DMP1-targeted Cre expression in odontoblasts and osteocytes. J Dent Res 2007, 86:320-325.

84. Chiu WS, McManus JF, Notini AJ, Cassady AI, Zajac JD, Davey RA: Transgenic mice that express Cre recombinase in osteoclasts. Genesis 2004, 39:178-185.

85. Garcia-Otin AL, Guillou F: Mammalian genome targeting using site-specific recombinases. Front Biosci 2006, 11: 1108-1136.

86. Takeda S, Elefteriou F, Levasseur R, Liu X, Zhao L, Parker KL, Armstrong D, Ducy P, Karsenty G: Leptin regulates bone formation via the sympathetic nervous system. Cell 2002, 111: 305-317.

87. Takeda S, Karsenty G: Molecular bases of the sympathetic regulation of bone mass. Bone 2008, 42:837-840.

88. Lee NK, Sowa H, Hinoi E, Ferron M, Ahn JD, Confavreux C, Dacquin R, Mee PJ, McKee MD, Jung DY, Zhang Z, Kim JK, Mauvais-Jarvis F, Ducy P, Karsenty G: Endocrine regulation of energy metabolism by the skeleton. Cell 2007, 130:456469.

89. Yadav VK, Ryu JH, Suda N, Tanaka KF, Gingrich JA, Schütz G, Glorieux FH, Chiang CY, Zajac JD, Insogna KL, Mann JJ, Hen R, Ducy P, Karsenty G: Lrp5 controls bone formation by inhibiting serotonin synthesis in the duodenum. Cell 2008, 135:825-837.

90. Hamrick MW, Ferrari SL: Leptin and the sympathetic connection of fat to bone. Osteoporos Int 2008, 19:905-912.

91. Gustafsson BI, Westbroek I, Waarsing JH, Waldum H, Solligard E, Brunsvik A, Dimmen S, van Leeuwen JP, Weinans $H$ Syversen $U$ : Long-term serotonin administration leads to higher bone mineral density, affects bone architecture, and leads to higher femoral bone stiffness in rats. J Cell Biochem 2006, 97:1283-1291.

92. Bonewald LF, Johnson ML: Osteocytes, mechanosensing and Wnt signaling. Bone 2008, 42:606-615.

93. Koboldt DC, Chen K, Wylie T, Larson DE, McLellan MD, Mardis ER, Weinstock GM, Wilson RK, Ding L: VarScan: variant detection in massively parallel sequencing of individual and pooled samples. Bioinformatics 2009, 25:2283-2285.

94. Biesecker LG, Mullikin JC, Facio FM, Turner C, Cherukuri PF, Blakesley RW, Bouffard GG, Chines PS, Cruz P, Hansen NF, Teer JK, Maskeri B, Young AC; NISC Comparative Sequencing 
Program, Manolio TA, Wilson AF, Finkel T, Hwang P, Arai A, Remaley AT, Sachdev V, Shamburek R, Cannon RO, Green ED: The ClinSeq Project: piloting large-scale genome sequencing for research in genomic medicine. Genome Res 2009, 19:1665-1674.

95. Tucker T, Marra M, Friedman JM: Massively parallel sequencing: the next big thing in genetic medicine. Am J Hum Genet 2009, 85:142-154.

96. Moore WJ, Kern JC, Bhat R, Commons TJ, Fukayama S, Goljer I, Krishnamurthy G, Magolda RL, Nogle L, Pitts K, Stauffer B, Trybulski EJ, Welmaker GS, Wilson M, Bodine PV: Modulation of Wnt signaling through inhibition of secreted frizzled-related protein I (sFRP-1) with N-substituted piperidinyl diphenylsulfonyl sulfonamides. J Med Chem 2009, 52:105-116.

97. Clement-Lacroix $\mathrm{P}, \mathrm{Ai} \mathrm{M}$, Morvan $\mathrm{F}$, Roman-Roman S, Vayssiere B, Belleville C, Estrera K, Warman ML, Baron R, Rawadi G: Lrp5-independent activation of wnt signaling by lithium chloride increases bone formation and bone mass in mice. Proc Natl Acad Sci USA 2005, 102:17406-17411.

98. Kulkarni $\mathrm{NH}$, Onyia JE, Zeng Q, Tian X, Liu M, Halladay DL, Frolik CA, Engler T, Wei T, Kriauciunas A, Martin TJ, Sato M, Bryant HU, Ma YL: Orally bioavailable GSK-3 $\alpha / \beta$ dual inhibitor increases markers of cellular differentiation in vitro and bone mass in vivo. J Bone Miner Res 2006, 21:910-920.

99. Morvan F, Boulukos K, Clément-Lacroix P, Roman Roman S, Suc-Royer I, Vayssière B, Ammann $P$, Martin $P$, Pinho $S$, Pognonec P, Mollat P, Niehrs C, Baron R, Rawadi G: Deletion of a single allele of the Dkk1 gene leads to an increase in bone formation and bone mass. J Bone Miner Res 2006, 21:934-945.

100. Yacoby S, Ling W, Zhan F, Walker R, Barlogie B, Shaughnessy JDJ: Anitbody-based inhibition of DKK1 suppresses tumor-induced bone resorption and multiple myeloma growth in vivo. Blood 2007, 109:2106-2111.

101. Kikuchi $A$ : Tumor formation by genetic mutations in the components of the wnt signaling pathway. Cancer Sci 2003, 94:225-229.

102. Logan CY, Nusse R: The Wnt signaling pathway in development and disease. Annu Rev Cell Dev Biol 2004, 20:781-810.

103. Moon RT, Bowerman B, Boutros M, Perrimon N: The promise and perils of wnt signaling through $\beta$-catenin. Science 2002, 296:1644-1646

104. Nusse R: Wnt signaling in disease and development. Cell Res 2005, 15:28-32.
105. Rawadi G, Roman-Roman S: Wnt signaling pathway: a new target for the treatment of osteoporosis. Expert Opin Ther targets 2005, 9:1063-1077.

106. Piters E, Bouding E, Van Hul W: Wnt signaling: A win for bone. Arch Biochem Biophys 2008, 473:112-116.

107. Kiel DP, Demissie S, Dupuis J, Lunetta KL, Murabito JM, Karasik D: Genome-wide association with bone mass and geometry in the Framingham Heart Study. BMC Med Genet 2007, 8(Suppl 1):S14.

108. Babij P, Zhao W, Small C, Kharode Y, Yaworsky PJ, Bouxsein ML, Reddy PS, Bodine PV, Robinson JA, Bhat B, Marzolf J, Moran RA, Bex F: High bone mass in mice expressing a mutant LRP5 gene. J Bone Miner Res 2003, 18:960-974.

109. Kato M, Patel MS, Levasseur R, Lobov I, Chang BH, Glass DA 2nd, Hartmann C, Li L, Hwang TH, Brayton CF, Lang RA, Karsenty G, Chan L: Cbfa 1-independent decrease in osteoblast proliferation, osteopenia, and persistent embryonic eye vascularization in mice deficient in Lrp5, a Wnt coreceptor. J Cell Biol 2002, 157:303-314.

110. Cho YS, Go MJ, Kim YJ, Heo JY, Oh JH, Ban HJ, Yoon D, Lee MH, Kim DJ, Park M, Cha SH, Kim JW, Han BG, Min H, Ahn Y, Park MS, Han HR, Jang HY, Cho EY, Lee JE, Cho NH, Shin C, Park T, Park JW, Lee JK, Cardon L, Clarke G, McCarthy MI, Lee JY, Lee JK, et al:: A large-scale genome-wide association study of Asian populations uncovers genetic factors influencing eight quantitative traits. Nat Genet 2009, 41: 527-534.

111. Nakanishi R, Akiyama H, Kimura H, Otsuki B, Shimizu M, Tsuboyama T, Nakamura T: Osteoblast-targeted expression of Sfrp4 in mice results in low bone mass. J Bone Miner Res 2008, 23:271-277.

112. McGuigan FE, Larzenius E, Callreus M, Gerdhem P, Luthman $\mathrm{H}$, Akesson $\mathrm{K}$ : Variation in the BMP2 gene: bone mineral density and ultrasound in young adult and elderly women. Calcif Tissue Int 2007, 81:254-262.

113. Kamiya N, Ye L, Kobayashi T, Lucas DJ, Mochida Y, Yamauchi M, Kronenberg HM, Feng JQ, Mishina Y: Disruption of BMP signaling in osteoblasts through type IA receptor (BMPRIA) increases bone mass. J Bone Miner Res 2008, 23: 2007-2017.

Published: 07 September 2009

doi:10.1186/gm84

(C) 2009 BioMed Central Ltd 